\title{
Pengaruh Suhu dan Waktu Pengeringan terhadap Aktivitas Antioksidan Teh Herbal Celup Daun Belimbing Wuluh (Averrhoa bilimbi L.)
}

\section{The Effect of Temperature and Drying Time on Antioxidant Activity of Herbal Tea Bag of Starfruit Leaves (Averrhoa billimbi L.)}

\author{
Ariani Nisfin Kholifah ${ }^{1}$, I Dewa Gde Mayun Permana ${ }^{1}$, N.L.A Yusasrini ${ }^{1}$
}

*Penulis korespondensi: I Dewa Gde Mayun Permana, Email: mayunpermana@unud.ac.id

\begin{abstract}
This research aimed to determine the effect of temperature and drying time on antioxidant activity of starfruit leaf herbal tea bags and to obtain the best drying temperature and time that can produce starfruit leaf herbal tea with the best antioxidant activity. This research was conducted by using experimental design with Complete Randomized Design factorial pattern of two factors which are drying temperature $\left(50^{\circ} \mathrm{C}, 60^{\circ} \mathrm{C}, 70^{\circ} \mathrm{C}\right)$ and drying time $(120$ minutes, 180 minutes, 240 minutes). There were 9 treatment combinations, each treatment combination was repeated 2 times so that the number of treatment combinations was 18 experimental units. The data obtained were analyzed by analysis of variance. If the treatment had a significant effect, it would be followed by the Duncan Multiple Range Test. The results showed that interaction beetwen drying temperature and time treatment had a very significant effect on antioxidant activity, total phenol, total flavonoids, water content of starfruit leaf herbal tea, and bitter flavor, and had no significant effect) on color, aroma, taste and overall acceptance. The drying temperature of $50^{\circ} \mathrm{C}$ with a drying time of 120 minutes was the best temperature and drying time to produce herbal tea bags of starfruit leaves with an antioxidant activity of $87.8049 \%$ and based on the IC 50 value of $10595.95 \mathrm{ppm}$, water content of $9.53 \%$, the total phenol content was $1.38 \mathrm{mg}$ $\mathrm{GAE} / \mathrm{g}$, the total flavonoid level was $0.94 \mathrm{mg} Q E / \mathrm{g}$, and sensory properties of color (liked), aroma (slight liked), flavor (slight bitter, slight liked) and overall acceptance (slightly liked).
\end{abstract}

Keywords: antioxidant, starfruit leaves, drying temperature and time, herbal tea bag

\section{PENDAHULUAN}

Belimbing wuluh (Averrhoa bilimbi L.) merupakan tanaman berbuah beriklim tropis yang masuk dan tumbuh dengan subur di seluruh wilayah Indonesia, salah satunya di Bali. Belimbing wuluh juga dikenal dengan nama lain balimbingan (Batak), limeng (Aceh), calene (Bugis), malimbi (Nias), bhalimbing bulu (Madura) (Mus, 2012). Tanaman ini terdiri dari beberapa bagian yaitu daun, bunga dan buah. Tanaman ini secara tradisional dipercaya dapat mengobati hipertensi, diabetes melitus, demam, radang poros usus, batuk, dan encok (Thomas,
2007). Hampir seluruh bagian dari tanaman belimbing wuluh dapat dimanfaatkan, salah satunya adalah bagian daun. Menurut Valsan dan Raphael (2016) komponen fitokimia yang terdapat pada daun belimbing wuluh adalah senyawa bioaktif seperti flavonoid dan fenol yang dapat berfungsi sebagai antioksidan. Menurut Hasim et al (2019) dalam penelitian ekstrak etanol daun belimbing wuluh, menghasilkan kadar total fenol dan flavonoid ekstrak daun belimbing wuluh secara berturut turut sebesar 39,03 $\pm 0,25 \mu \mathrm{g}$ $\mathrm{GAE} / \mathrm{mg}$ ekstrak dan 97,28 $\pm 1,38 \mu \mathrm{g} \mathrm{QE} / \mathrm{mg}$. Komponen fitokimia dalam daun belimbing wuluh 
menunjukkan bahwa daun belimbing wuluh memiliki potensi untuk diolah sebagai produk pangan.

Pengolahan tanaman belimbing wuluh sebagai produk pangan sudah banyak ditemukan pada pemanfaatan buahnya, namun untuk pemanfaatan daun belimbing wuluh masih belum banyak ditemukan. Masyarakat Indonesia biasanya memanfaatkan daun belimbing wuluh sebagai minuman herbal untuk obat tradisional dengan cara direbus bersama bunga dan buah belibing wuluh. Salah satu alternatif pengolahan daun belimbing wuluh adalah diolah menjadi teh herbal. Menurut Winarsi (2007) teh herbal merupakan proses pengolahan teh yang dibuat dengan bahan yang bukan dari daun teh (Camellia sinensis). Keunggulan dari teh herbal dapat dikonsumsi sebagai minuman sehat yang praktis tanpa mengganggu rutinitas sehari-hari dan tetap menjaga kesehatan tubuh (Verma et al., 2014). Dalam proses penyajian, teh herbal dapat dilakukan dengan cara dicelup karena proses penyeduhan teh celup sangat mudah dan praktis. Pembuatan teh herbal dari daun belimbing wuluh dapat dilakukan dengan cara pengeringan. Terdapat beberapa metode pengeringan dalam pembuatan teh herbal salah satunya yaitu menggunakan oven. Menurut Hartuti dan Sinaga (1997) pengeringan dengan oven memiliki keunggulan yaitu suhu pengeringan yang mudah diatur.

Salah satu faktor yang mempengaruhi pengeringan adalah suhu dan waktu proses pengeringan. Suhu dan waktu pengeringan yang berbeda memberikan perbedaan yang nyata terhadap perolehan kadar senyawa aktivitas antioksidan (Wulandari, 2009). Penelitian yang telah dilakukan oleh Adri et al., (2013) melaporkan bahwa waktu pengeringan 150 menit dengan menggunakan suhu $50^{\circ} \mathrm{C}$ menghasilkan teh herbal daun sirsak terbaik dengan nilai $\mathrm{IC}_{50} 82,16 \mu \mathrm{g} / \mathrm{ml}$. Sementara itu, Sari (2015), melaporkan pada pengeringan dengan suhu $50^{\circ} \mathrm{C}$ dengan waktu pengeringan 120 menit menghasilkan hasil terbaik dari teh herbal daun alpukat. Hasil terbaik aktivitas antioksidan penelitian teh herbal daun ketepeng cina yaitu menggunakan suhu $50^{\circ} \mathrm{C}$ dan waktu pnegeringan 130 menit (Yamin et al ., 2017). Penentuan suhu dan waktu pengeringan saat berpengaruh terhadap karakteristik teh herbal yang dihasilkan. Simanjuntak et al. (2014), melaporkan bahwa penggunaan suhu yang terlalu tinggi dapat menyebabkan beberapa senyawa antioksidan yang terkandung dalam bahan rusak. Hal ini juga diperkuat oleh penelitian yang dilakukan oleh Andarwulan et al. (1996), yang menyatakan bahwa pemanasan yang dilakukan cukup lama dan menggunakan temperatur yang tinggi dapat menurunkan aktivitas antioksidan yang terkandung dalam produk tersebut. Suhu pengeringan teh berkisar antara $30^{\circ} \mathrm{C}-90^{\circ} \mathrm{C}$ namun suhu terbaik untuk pengeringan sebaiknya tidak melebihi $60^{\circ} \mathrm{C}$ (Liliana, 2005).

Penelitian mengenai suhu dan waktu pengeringan teh herbal sudah banyak dilakukan, namun pemanfaatan daun belimbing wuluh menjadi teh herbal belum dilakukan. Penelitian ini bertujuan untuk mengetahui pengaruh suhu dan waktu pengeringan terhadap aktivitas antioksidan 
dan sifat sensoris teh herbal celup daun belimbing wuluh.

\section{METODE PENELITIAN}

\section{Tempat dan Waktu}

Penelitian ini dilaksanakan di Laboratorium Analisis Pangan, Laboratorium Pengolahan Pangan, Laboratorium Biokimia Pangan dan Nutrisi dan Laboratorium Rekayasa. Program Studi Teknologi Pangan, Fakultas Teknologi Pertanian Universitas Udayana. Pelaksanaan penelitian ini dilakukan pada bulan Juli 2020 September 2020.

\section{Bahan dan Alat}

Bahan yang digunakan dalam penelitian ini mencakup bahan utama dan bahan kimia. Bahan utama pada penelitian ini adalah daun belimbing wuluh (Averrhoa billimbi L.) dari daerah Bukit Jimbaran dengan kriteria daun yang digunakan yaitu nomor 3 sampai 8 dari pucuk daun. Bahan kimia yang digunakan terdiri dari akuades, alkohol (Merck, Germany), $\mathrm{NaOH}$ (Merck, Germany), $\mathrm{Na} 2 \mathrm{CO} 3 \quad$ (Merck, Germany), $\mathrm{AlCl} 3$ (Merck, Germany), kuersetin (Sigma Aldrich,USA), reagen

Folin-Ciocalteal

(Merck,Germany), metanol (Merck,Germany), HCL (Merck,Germany), metanol PA (Merck,Germany), DPPH (1,1-diphenyl-2picrylhydrazyl) (Sigma Aldrich,USA).

Alat yang digunakan adalah oven, loyang, aluminium foil, pinset, kuas, timbangan analitik (Shimadzu ATY224, Jepang), cawan aluminium, cawan porselin,labu ukur (Pyrex, USA), kompor listrik, gelas beaker (Pyrex, USA), gelas ukur (Pyrex, USA), tabung reaksi (Pyrex, USA), pipet tetes, spektrofotometer (Biochromsn 133467, UK), alat sentrifugasi (Damon IEC Division, USA), dandang ukuran $30 \mathrm{~cm}$, blender (Philips, Indonesia), spatula, desikator, pipet volume, pipet mikro (Dragon Lab, Indonesia), erlenmeyer (Pyrex, USA), vortex (Barnsteadl Thermolyne Type 37600 Mixer, USA), ayakan 40 mesh (ABM, Indonesia), cup untuk uji sensoris.

\section{Rancangan Penelitian}

Rancangan percobaan yang digunakan dalam penelitian ini Rancangan Acak Lengkap (RAL) Pola Faktorial dengan 2 faktor, faktor pertama suhu pengeringan (S) terdiri dari 3 taraf yaitu $\mathrm{S} 1\left(50^{\circ} \mathrm{C}\right), \mathrm{S} 2\left(60^{\circ} \mathrm{C}\right), \mathrm{S} 3\left(70^{\circ} \mathrm{C}\right)$ sedangkan faktor kedua yaitu waktu pengerigan (W) terdiri dari 3 taraf yaitu W1 (120 menit), W2 (180 menit), W3 (240 menit) dimana perlakuan ini diulang sebanyak 2 kali sehingga diperoleh 18 unit percobaan. Kemudian dianalisis dengan menggunakan analisis ragam (ANOVA) dan apabila terdapat pengaruh antar taraf perlakuan maka dilanjutkan dengan Uji Jarak Berganda Duncan.

\section{Pelaksanaan penelitian}

\section{Persiapan Bahan}

Daun belimbing wuluh segar disiapkan kemudian dilanjutkan dengan sortasi bahan baku dengan memilih daun belimbing wuluh untuk menghilangkan tangkai dan yang rusak. Daun belimbing wuluh yang lolos tahap sortasi dibersihkan untuk menghilangkan debu atau kotoran yang menempel pada permukaan daun.

\section{Pelayuan}

Proses pelayuan dilakukan dengan menggunakan metode steaming pada suhu uap 
$80^{\circ} \mathrm{C}$ selama 2 menit, selanjutnya dilakukan pendinginan selama 5 menit dalam suhu ruang (Aprillia et al., 2020).

\section{Pengeringan}

Pengeringan dilakukan sesuai dengan perlakuan dengan suhu $50^{\circ} \mathrm{C}, 60^{\circ} \mathrm{C}$, dan $70^{\circ} \mathrm{C}$ selama 120 menit, 180 menit, dan 240 menit. Bahan yang digunakan pada masing-masing perlakuan adalah 200 g. Daun belimbing wuluh yang sudah dikeringkan kemudian dihancurkan dengan blender dan dilakukan pengayakan menggunakan ayakan 40 mesh sehingga didapatkan bubuk teh herbal daun belimbing wuluh. Bubuk daun belimbing wuluh ditimbang 2 g kemudian dikemas dengan teabag ukuran $6,5 \mathrm{~cm}$ $\mathrm{x} 5,5 \mathrm{~cm}$. Sehingga didapat produk teh celup.

\section{Penyeduhan}

Proses penyeduhan dilakukan untuk menguji karakteristik sensoris dari teh herbal daun belimbing wuluh. Teh herbal celup daun belimbing wuluh diseduh dengan air bersuhu $100^{\circ} \mathrm{C}$ sebanyak $200 \mathrm{ml}$. Penyeduhan dilakukan selama 5 menit dengan kantong teh celup yang digerakkan naik turun dalam air secara konstan (terus menerus atau berkelanjutan). Setelah proses pencelupan selesai kemudian kantong teh celup dikeluarkan dan dihasilkan minuman teh herbal celup daun belimbing wuluh (Anon., 2014). Hasil seduhan diuji secara sensoris (warna, aroma, rasa, dan penerimaan keseluruhan).

\section{Variabel yang Diamati}

Variabel yang diamati dalam penelitian ini adalah kadar air metode pengeringan (Sudarmadji et al., 1997), total fenol metode spektrofotometri (Sakanata et al., 2003), total flavonoid metode spektrofotometri (Rahman et al., 2006), aktivitas antioksidan metode DPPH (Sompong et al., 2011), dan sifat sensoris yang meliputi warna, aroma, rasa, dan penerimaan keseluruhan (Soekarto, 1985).

\section{HASIL DAN PEMBAHASAN}

\section{Kadar Air}

Hasil penelitian pengaruh suhu dan waktu pengeringan pada teh herbal celup daun belimbing wuluh terhadap kadar air dapat dilihat pada Tabel 1.

Tabel 1. Nilai rata- rata kadar air (\%) teh herbal celup daun belimbing wuluh dengan perlakuan suhu dan waktu pengeringan.

\begin{tabular}{cccc}
\hline Suhu Pengeringan $\left({ }^{\circ} \mathrm{C}\right)$ & \multicolumn{3}{c}{ Waktu Pengeringan (menit) } \\
\cline { 2 - 4 } & $120(\mathrm{~W} 1)$ & $180(\mathrm{~W} 2)$ & $240(\mathrm{~W} 3)$ \\
\hline $50(\mathrm{~S} 1)$ & $9,53 \pm 0,003 \mathrm{a}$ & $9,31 \pm 0,02 \mathrm{~b}$ & $8,92 \pm 0,04 \mathrm{c}$ \\
& $\mathrm{a}$ & $\mathrm{a}$ & $\mathrm{a}$ \\
$60(\mathrm{~S} 2)$ & $8,61 \pm 0,01 \mathrm{a}$ & $8,43 \pm 0,01 \mathrm{~b}$ & $8,31 \pm 0,09 \mathrm{~b}$ \\
& $\mathrm{~b}$ & $\mathrm{~b}$ & $\mathrm{~b}$ \\
$70(\mathrm{~S} 3)$ & $8,08 \pm 0,01 \mathrm{a}$ & $7,80 \pm 0,08 \mathrm{~b}$ & $7,62 \pm 0,08 \mathrm{~b}$ \\
& $\mathrm{c}$ & $\mathrm{c}$ & $\mathrm{c}$ \\
\hline
\end{tabular}

Keterangan: Nilai rata-rata \pm standar deviasi $(\mathrm{n}=2)$. Huruf yang sama dibelakang nilai rata-rata pada baris yang sama atau dibawah nilai rata-rata pada kolom yang sama menunjukkan perlakuan berbeda sangat nyata $(\mathrm{P}<0,01)$. 
Hasil dari sidik ragam menunjukkan bahwa interaksi antara suhu dan waktu pengeringan berpengaruh sangat nyata $(\mathrm{P}<0,01)$ terhadap kadar air teh herbal celup daun belimbing wuluh yang dapat dilihat pada tabel 1 . Tabel 1 menunjukkan bahwa kadar air teh herbal celup daun belimbing wuluh berkisar antara 7,62\%-9,53\%. Kadar air tertinggi diperolah pada perlakuan suhu pengeringan $50^{\circ} \mathrm{C}$ dengan waktu 120 menit yaitu 9,53\%, sedangkan kadar air terendah diperoleh pada perlakuan suhu pengeringan $70^{\circ} \mathrm{C}$ dengan waktu 240 menit yaitu $7,62 \%$. Hal ini menunjukkan bahwa pengaruh suhu dan waktu pengeringan sangat berpengaruh terhadap kadar air teh herbal celup daun belimbing wuluh. Hal ini disebabkan oleh perpindahan panas, dimana energi panas yang diberikan bergerak menuju bahan yang memiliki panas lebih rendah sehingga semakin tinggi suhu dan semakin lama pengeringan, maka semakin besar energi panas yang dibawa udara. Energi panas yang diterima akan mengubah kandungan air di dalam bahan menjadi uap, sehingga uap air akan berpindah ke permukaan bahan dan kemudian dilepaskan ke lingkungan bahan. Menurut Suksmadji (1987), adanya pemanasan pada bahan pangan juga akan menyebabkan dinding sel menjadi lunak dan permeabel terhadap air, sehingga proses penguapan air pada bahan terjadi secara cepat. Umumnya perlakuan panas yang berlebihan akan merusak sifat osmotik dinding sel dan turgor sel yang dapat menurunkan elastisitas dinding sel, sehingga mengurangi kemampuan jaringan untuk memerangkap air (Neuma, 1972).
Hal tersebut juga didukung oleh pernyataan dari Winarno (1995) bahwa semakin tinggi suhu dan lama pengeringan dapat menyebabkan semakin rendahnya kandungan kadar air yang disebabakan proses penguapan yang semakin cepat. Pernyatan tersebut diperkuat oleh Dewi et al. (2016) bahwa semakin lama waktu yang diperlukan untuk pengeringan, maka panas yang diterima oleh bahan tersebut juga semakin lama dan menyebabkan kadar air dalam bahan tersebut semakin turun. Hal ini sesuai dengan penelitian yag dilakukan oleh Martini et al. (2020), bahwa kadar air teh herbal daun telang semakin rendah diakibatkan semakin lama dan tingginya suhu pengeringan. Jika dibandingkan dengan SNI 014324-1996 tentang syarat mutu teh celup, standar kadar air teh celup yaitu maksimal 10\%, kadar air pada teh herbal celup daun belimbing wuluh pada semua perlakuan telah memenuhi standar yang telah ditetapkan.

\section{Kadar Total Fenol}

Hasil penelitian pengaruh suhu dan waktu pengeringan pada teh herbal celup daun belimbing wuluh terhadap kadar total fenol dapat dilihat pada Tabel 2.

Hasil sidik ragam menunjukkan bahwa interaksi antara suhu dan waktu pengeringan berpengaruh sangat nyata $(\mathrm{P}<0,01)$ terhadap total fenol teh herbal celup daun belimbing wuluh yang dapat dilihat pada tabel 2. Tabel 2 menunjukkan bahwa total fenol pada teh herbal celup daun belimbing wuluh berkisar antara $0,84 \mathrm{mg} \mathrm{GAE} / \mathrm{g}-$ 1,38 mg GAE/g. Total fenol tertinggi diperoleh pada perlakuan suhu pengeringan $50^{\circ} \mathrm{C}$ dengan waktu 120 menit yaitu $1,38 \mathrm{mg}$ GAE/g sedangkan 
total fenol terendah diperoleh pada suhu pengeringan $70^{\circ} \mathrm{C}$ dengan waktu 240 menit yaitu $0,84 \mathrm{mg} \mathrm{GAE} / \mathrm{g}$.

Berdasarkan data yang diperoleh terjadi penurunan nilai total fenol pada perlakuan suhu $50^{\circ} \mathrm{C}$ waktu 120 hingga suhu $70^{\circ} \mathrm{C}$ waktu 240 menit. Hal ini diduga bahwa fenol pada teh herbal celup daun belimbing wuluh optimum pada suhu pengeringan $50^{\circ} \mathrm{C}$ dengan waktu 120 menit. Kadar fenol pada suhu dan waktu yang meningkat melebihi suhu dan waktu optimumnya akan mengalami penurunan disebabkan karena fenol mengalami oksidasi pada perlakuan tersebut. Hal ini sejalan dengan penelitian Susanti (2008) menyatakan kadar fenol daun kering gambir akan mengalami peningkatan seiring dengan naiknya suhu dan naiknya waktu pengeringan akan tetapi pada suhu dan waktu yang meningkat melebihi suhu dan waktu optimumnya, kadar fenol akan mengalami penurunan. Hal tersebut juga sesuai dengan hasil penelitian dari Martini et al. (2020) yaitu semakin tinggi suhu dan semakin lama waktu pengeringan mengakibatkan penurunan kandungan fenol pada teh herbal bunga telang.

Tabel 2. Nilai rata- rata kadar total fenol (mg GAE/g) teh herbal celup daun belimbing wuluh dengan perlakuan suhu dan waktu pengeringan.

Suhu Pengeringan $\left({ }^{\circ} \mathrm{C}\right)$

\begin{tabular}{cccc} 
& $120(\mathrm{~W} 1)$ & $180(\mathrm{~W} 2)$ & $240(\mathrm{~W} 3)$ \\
\hline $50(\mathrm{~S} 1)$ & $1,38 \pm 0,028 \mathrm{a}$ & $1,24 \pm 0,006 \mathrm{~b}$ & $1,16 \pm 0,009 \mathrm{c}$ \\
& $\mathrm{a}$ & $\mathrm{a}$ & $\mathrm{a}$ \\
$60(\mathrm{~S} 2)$ & $1,08 \pm 0,027 \mathrm{a}$ & $1,01 \pm 0,001 \mathrm{~b}$ & $0,99 \pm 0,019 \mathrm{~b}$ \\
& $\mathrm{~b}$ & $\mathrm{~b}$ & $\mathrm{~b}$ \\
$70(\mathrm{~S} 3)$ & $0,92 \pm 0,012 \mathrm{a}$ & $0,88 \pm 0,007 \mathrm{a}$ & $0,84 \pm 0,019 \mathrm{~b}$ \\
& $\mathrm{c}$ & $\mathrm{c}$ & $\mathrm{c}$
\end{tabular}

Keterangan: Nilai rata- rata \pm standar deviasi $(\mathrm{n}=2)$. Huruf yang sama dibelakang nilai rata-rata pada baris yang sama atau dibawah nilai rata-rata pada kolom yang sama menunjukkan perlakuan berbeda sangat nyata $(\mathrm{P}<0,01)$.

\section{Kadar Total Flavonoid}

Hasil penelitian pengaruh suhu dan waktu pengeringan pada teh herbal celup daun belimbing wuluh terhadap kadar total flavonoid dapat dilihat pada Tabel 3.

Tabel 3. Nilai rata- rata kadar total flavonoid ( $\mathrm{mg} \mathrm{QE} / \mathrm{g}$ ) teh herbal celup daun belimbing wuluh dengan perlakuan suhu dan waktu pengeringan

Suhu Pengeringan $\left({ }^{\circ} \mathrm{C}\right)$

Waktu Pengeringan (menit)

\begin{tabular}{cccc} 
& $120(\mathrm{~W} 1)$ & $180(\mathrm{~W} 2)$ & $240(\mathrm{~W} 3)$ \\
\hline $50(\mathrm{~S} 1)$ & $0,94 \pm 0,003 \mathrm{a}$ & $0,78 \pm 0,027 \mathrm{~b}$ & $0,70 \pm 0,013 \mathrm{c}$ \\
& $\mathrm{a}$ & $\mathrm{a}$ & $\mathrm{a}$ \\
$60(\mathrm{~S} 2)$ & $0,67 \pm 0,023 \mathrm{a}$ & $0,64 \pm 0,011 \mathrm{a}$ & $0,58 \pm 0,011 \mathrm{~b}$ \\
& $\mathrm{~b}$ & $\mathrm{~b}$ & $\mathrm{~b}$ \\
$70(\mathrm{~S} 3)$ & $0,55 \pm 0,029 \mathrm{a}$ & $0,53 \pm 0,004 \mathrm{a}$ & $0,45 \pm 0,014 \mathrm{~b}$ \\
& $\mathrm{c}$ & $\mathrm{c}$ & $\mathrm{c}$
\end{tabular}

Keterangan: Nilai rata- rata \pm standar deviasi $(\mathrm{n}=2)$. Huruf yang sama dibelakang nilai rata-rata pada baris yang sama atau dibawah nilai rata-rata pada kolom yang sama menunjukkan perlakuan berbeda sangat nyata $(\mathrm{P}<0,01)$. 
Hasil sidik ragam menunjukkan bahwa interaksi suhu dan waktu pengeringan berpengaruh sangat nyata $(\mathrm{P}<0,01)$ terhadap total flavonoid teh herbal celup daun belimbing wuluh, yang dapat dilihat pada tabel 3. Tabel 3 menunjukkan bahwa total flavonoid teh herbal celup daun belimbing wuluh berkisar antara $0,45 \mathrm{mg} \mathrm{QE} / \mathrm{g}-0,94 \mathrm{mg}$ QE/g. Kadar total flavonoid tertinggi diperoleh pada perlakuan suhu pengeingan $50^{\circ} \mathrm{C}$ dengan waktu 120 menit yaitu $0,94 \mathrm{mg}$ QE/g sedangkan kadar total flavonoid terendah diperoleh pada perlakuan suhu pengeringan $70^{\circ} \mathrm{C}$ dengan waktu 240 menit yaitu $0,45 \mathrm{mg} \mathrm{QE} / \mathrm{g}$.

Berdasarkan data yang diperoleh terjadi penurunan nilai total flavonoid pada perlakuan suhu $50^{\circ} \mathrm{C}$ waktu 120 hingga suhu $70^{\circ} \mathrm{C}$ waktu 240 menit. Penurunan nilai total flavonoid salah satunya disebabkan oleh suhu dan lama waktu pemanasan. Hal ini sesuai dengan pernyataan menurut Zainol et al. (2009) bahwa penurunan kandungan flavonoid disebabkan oleh pemanasan dengan suhu dan waktu yang tinggi, dan juga semakin tinggi suhu yang disertai waktu pemanasan yang semakin lama akan mengakibatkan senyawa flavonoid rusak sehingga terjadi penurunan kandungan flavonoid. Selain itu, Dewi et al. (2017) juga melaporkan bahwa suhu dan waktu pengeringan dapat mengakibatkan menghilangnya beberapa senyawa fenolik dengan berat molekul rendah seperti flavonoid.

\section{Aktivitas Antioksidan}

Hasil penelitian pengaruh suhu dan waktu pengeringan pada teh herbal celup daun belimbing wuluh terhadap aktivitas antioksidan dapat dilihat pada Tabel 4.

Tabel 4. Nilai rata- rata Aktivitas Antioksidan teh herbal celup daun belimbing wuluh dengan perlakuan suhu dan waktu pengeringan

\begin{tabular}{cccc}
\hline $\begin{array}{c}\text { Suhu Pengeringan } \\
\left({ }^{\circ} \mathrm{C}\right)\end{array}$ & $120(\mathrm{~W} 1)$ & $180(\mathrm{~W} 2)$ & $240(\mathrm{~W} 3)$ \\
& & & \\
\cline { 2 - 4 } & $87,8049 \pm 0,25 \mathrm{a}$ & $83,8850 \pm 0,12 \mathrm{~b}$ & $80,4878 \pm 0,25 \mathrm{c}$ \\
$50(\mathrm{~S} 1)$ & $\mathrm{a}$ & $\mathrm{a}$ & $\mathrm{a}$ \\
& $80,1393 \pm 0,74 \mathrm{a}$ & $76,9164 \pm 0,12 \mathrm{~b}$ & $69,1637 \pm 0,25 \mathrm{c}$ \\
$60(\mathrm{~S} 2)$ & $\mathrm{b}$ & $\mathrm{b}$ & $\mathrm{b}$ \\
& $67,7700 \pm 0,99 \mathrm{a}$ & $64,3728 \pm 1,11 \mathrm{~b}$ & $60,2787 \pm 0,49 \mathrm{c}$ \\
$70(\mathrm{~S} 3)$ & $\mathrm{c}$ & $\mathrm{c}$ & $\mathrm{c}$
\end{tabular}

Keterangan: Nilai rata- rata \pm standar deviasi $(\mathrm{n}=2)$. Huruf yang sama dibelakang nilai rata-rata pada baris yang sama atau dibawah nilai rata-rata pada kolom yang sama menunjukkan perlakuan berbeda sangat nyata $(\mathrm{P}<0,01)$.

Hasil sidik ragam menunjukan bahwa interaksi antara suhu dan waktu pengeringan berpengaruh sangat nyata $(\mathrm{P}<0,01)$ terhadap aktivitas antioksidan teh herbal celup daun belimbing wuluh, yang dapat dilihat pada tabel 4 .
Tabel 4 menunjukkan hasil penelitian, nilai ratarata aktivitas antioksidan teh herbal celup daun belimbing wuluh berkisar $60,2787 \%-87,8049 \%$. Nilai rata- rata aktivitas antioksidan tertinggi diperoleh pada perlakuan suhu $50^{\circ} \mathrm{C}$ dengan waktu 
120 menit yaitu $87,8049 \%$, sedangkan nilai ratarata terendah terdapat pada perlakuan suhu $70^{\circ} \mathrm{C}$ dengan waktu 240 menit yaitu 60,2787\%. Hasil penelitian menunjukkan semakin tinggi suhu dan waktu pengeringan maka semakin rendah nilai persentase aktivitas antioksidannya. Selain itu, terdapat korelasi positif antara nilai total fenol, total flavonoid dan aktivitas antioksidan yang dihasilkan. Hal ini sesuai dengan laporan menurut Patras et al. (2009) bahwa senyawa bioaktif yang berfungsi sebagai antioksidan akan mudah terdegradasi jika terkena suhu tinggi dengan waktu pemanasan yang lama. Hal tersebut juga sesuai dengan pernyataan dari Prabandari (2015) bahwa terdapat korelasi positif antara aktivitas antioksidan dengan total fenol dan flavonoid, dimana semakin meningkatnya total fenol dan flavonoid, maka aktivitas antioksidan akan semakin meningkat begitu juga sebaliknya. Hal tersebut juga sesuai dengan pernyataan dari Zuhra et al. (2008) bahwa flavonoid merupakan senyawa fenolik yang bersifat sebagai antioksidan, sehingga semakin tinggi total flavonoidnya, maka semakin tinggi aktivitas antioksidannya.

Berdasarkan hasil analisis aktivitas antioksidan teh herbal celup daun belimbing wuluh dalam perlakuan pengeringan suhu $50^{\circ} \mathrm{C}$ dengan lama waktu 120 menit memiliki persentase aktivitas antioksidan tertinggi sehingga perlakuan ini dipilih untuk penentuan $\mathrm{IC}_{50}$. Nilai $\mathrm{IC}_{50}$ yang diperoleh sebesar 10959,95 ppm. Nilai aktivitas antioksidan memiliki korelasi negatif atau berbanding terbalik dengan $\mathrm{IC}_{50}$ dimana semakin kecil nilai $\mathrm{IC}_{50}$ maka semakin tinggi aktivitas antioksidan, sebaliknya semakin besar nilai $\mathrm{IC}_{50}$ maka semakin rendah aktivitas antioksidan. Hal ini sesuai dengan pernyataan dari Sari (2011) bahwa semakin tinggi nilai $\mathrm{IC}_{50}$ maka aktivitas antioksidan semakin rendah. Secara spesifik, suatu senyawa dikatakan sebagai antioksidan sangat kuat jika nilai $\mathrm{IC}_{50}$ kurang dari $50 \mathrm{ppm}$, kuat untuk $\mathrm{IC}_{50}$ antara $50-100 \mathrm{ppm}$, sedang jika nilai $\mathrm{IC}_{50}$ bernilai $101-150$ ppm, lemah jika $\mathrm{IC}_{50}$ bernilai 151 - 200 ppm dan sangat lemah jika $\mathrm{IC}_{50}$ bernilai lebih dari 200 ppm (Rahmawati, 2004). Sehingga dapat disimpulkan bahwa pada teh celup herbal celup daun belimbing wuluh memiliki potensi antioksidan sangat lemah dimana nilai $\mathrm{IC}_{50}$ menunjukkan lebih dari 200 ppm.

\section{Sifat Sensoris}

Sifat sensoris minuman teh herbal celup daun belimbing wuluh dilakukan dengan uji hedonik terhadap warna, aroma, rasa, penerimaan keseluruhan dan uji skoring rasa sepat. Dalam uji sensoris teh herbal celup daun belimbing wuluh hanya diuji perlakuan dengan Rancangan Acak Lengkap dan ulangannya adalah jumlah panelis.

Hasil penelitian mengenai pengaruh suhu dan waktu pengeringan pada teh herbal celup daun rambusa terhadap sifat sensoris dapat dilihat pada Tabel 5.

\section{Warna}

Hasil sidik ragam menunjukkan bahwa perlakuan suhu dan waktu pengeringan tidak berpengaruh nyata $(\mathrm{P}>0,05)$ terhadap warna teh herbal celup daun belimbing wuluh yang dilakukan dengan uji hedonik. Tabel 5 menunjukkan bahwa nilai rata-rata warna teh herbal celup daun belimbing wuluh tertinggi diperoleh pada perlakuan suhu pengeringan $70^{\circ} \mathrm{C}$ dengan waktu 
240 menit dengan nilai 3,60 (suka) sedangkan nilai rata-rata warna teh herbal celup daun belimbing wuluh terendah diperoleh pada perlakuan suhu pengeringan $50^{\circ} \mathrm{C}$ dengan waktu 120 menit dan 180 menit dengan nilai 3,20 (agak suka) dengan kriteria dari agak suka sampai suka.

\section{Aroma}

Hasil sidik ragam menunjukkan bahwa suhu dan waktu pengeringan tidak berpengaruh nyata $(\mathrm{P}>0,05)$ terhadap uji hedonik aroma minuman teh herbal celup daun belimbing wuluh. Tabel 5 menunjukkan bahwa nilai rata- rata uji hedonik aroma minuman teh herbal celup daun belimbing wuluh berkisar antara 3,00 (agak suka) sampai dengan 3,36 (agak suka). Menurut Fellow (1998), aroma dalam bahan makanan dapat ditimbulkan oleh komponen volatil, akan tetapi komponen volatil tersebut dapat hilang selama proses pengolahan terutama panas.

Tabel 5. Nilai rata- rata uji hedonik teh herbal celup daun belimbing wuluh

\begin{tabular}{ccccc}
\hline & \multicolumn{4}{c}{ Nilai Rata - Rata } \\
\cline { 2 - 5 } Perlakuan & Rasa & Aroma & Warna & Penerimaan Keseluruhan \\
\cline { 2 - 5 } S1W1 & $2,92 \pm 0,57 \mathrm{a}$ & $3,36 \pm 0,70 \mathrm{a}$ & $3,20 \pm 0,65 \mathrm{a}$ & $3,12 \pm 0,60 \mathrm{ab}$ \\
S1W2 & $2,92 \pm 0,57 \mathrm{a}$ & $3,36 \pm 0,70 \mathrm{a}$ & $3,20 \pm 0,71 \mathrm{a}$ & $3,12 \pm 0,44 \mathrm{ab}$ \\
S1W3 & $2,80 \pm 0,76 \mathrm{a}$ & $3,36 \pm 0,64 \mathrm{a}$ & $3,28 \pm 0,74 \mathrm{a}$ & $3,12 \pm 0,60 \mathrm{ab}$ \\
S2W1 & $2,88 \pm 0,83 \mathrm{a}$ & $3,24 \pm 0,60 \mathrm{ab}$ & $3,32 \pm 0,48 \mathrm{a}$ & $3,28 \pm 0,54 \mathrm{ab}$ \\
S2W2 & $2,88 \pm 0,83 \mathrm{a}$ & $3,24 \pm 0,66 \mathrm{ab}$ & $3,36 \pm 0,65 \mathrm{a}$ & $3,40 \pm 0,50 \mathrm{a}$ \\
S2W3 & $2,88 \pm 0,78 \mathrm{a}$ & $3,24 \pm 0,66 \mathrm{ab}$ & $3,48 \pm 0,76 \mathrm{a}$ & $3,36 \pm 0,64 \mathrm{a}$ \\
S3W1 & $3,04 \pm 0,89 \mathrm{a}$ & $3,24 \pm 0,72 \mathrm{ab}$ & $3,52 \pm 0,71 \mathrm{a}$ & $3,32 \pm 0,63 \mathrm{ab}$ \\
S3W2 & $2,96 \pm 0,84 \mathrm{a}$ & $3,00 \pm 0,76 \mathrm{~b}$ & $3,56 \pm 0,71 \mathrm{a}$ & $3,16 \pm 0,69 \mathrm{ab}$ \\
S3W3 & $2,84 \pm 0,80 \mathrm{a}$ & $3,12 \pm 0,67 \mathrm{ab}$ & $3,60 \pm 0,76 \mathrm{a}$ & $3,04 \pm 0,61 \mathrm{~b}$ \\
\hline
\end{tabular}

Keterangan: Nilai rata-rata yang diikuti oleh huruf yang sama pada kolom yang sama menunjukkan berbeda tidak nyata $(\mathrm{P}>0,05)$.

Kriterian hedonik : 1 (sangat tidak suka), 2 (tidak suka), 3 (agak suka), 4 (suka), dan 5 (sangat suka)

Tabel 6. Nilai rata- rata uji skoring rasa sepat teh herbal celup daun belimbing wuluh

\begin{tabular}{ll}
\hline Perlakuan & Nilai Rata-rata \\
\cline { 2 - 2 } & Rasa Sepat \\
\hline S1W1 & $2,92 \pm 1,04 \mathrm{ab}$ \\
S1W2 & $3,08 \pm 1,00 \mathrm{ab}$ \\
S1W3 & $3,16 \pm 0,85 \mathrm{a}$ \\
S2W1 & $2,72 \pm 0,74 \mathrm{bcd}$ \\
S2W2 & $2,84 \pm 0,75 \mathrm{abc}$ \\
S2W3 & $2,52 \pm 0,87 \mathrm{cde}$ \\
S3W1 & $2,44 \pm 0,92 \mathrm{de}$ \\
S3W2 & $2,28 \pm 0,85 \mathrm{e}$ \\
S3W3 & $2,16 \pm 0,84 \mathrm{e}$ \\
\hline
\end{tabular}

Keterangan: Nilai rata-rata yang diikuti oleh huruf yang tidak sama pada kolom yang sama menunjukkan berbeda sangat nyata $(\mathrm{P}<0,05)$.

Kriteria skoring : 1 (tidak sepat), 2 (sedikit sepat), 3 (agak sepat), 4 (sepat), 5 (sangat sepat). 


\section{Rasa}

Hasil sidik ragam menunjukkan bahwa perlakuan suhu dan waktu pengeringan berpengaruh nyata $(\mathrm{P}<0,05)$ terhadap rasa sepat teh herbal celup daun belimbing wuluh yang dilakukan dengan uji skoring. Tabel 5 menunjukkan bahwa nilai rata-rata rasa sepat teh herbal celup daun belimbing wuluh tertinggi diperoleh pada perlakuan suhu pengeringan $50^{\circ} \mathrm{C}$ dan waktu pengeringan 240 menit dengan nilai 3,16 (agak sepat) sedangkan nilai rata-rata rasa teh herbal celup daun belimbing wuluh terendah diperoleh pada suhu pengeringan $70^{\circ} \mathrm{C}$ dengan waktu pengeringan 240 menit dengan nilai 2,16 (sedikit sepat) dengan kriteria dari sedikit sepat sampai agak sepat. Rasa sepat yang terdapat pada teh berasal dari kandungan senyawa tannin pada bahan baku teh. Hal ini didukung oleh pernyataan Robinson (1995), bahwa tanin yang terdapat pada daun merupakan golongan senyawa aktif tumbuhan yang termasuk golongan flavonoid dan memiliki rasa sepat. Rasa sepat dapat menurun akibat senyawa tanin yang terkandung dalam bahan baku mengalami oksidasi akibat proses pemanasan.

Hasil sidik ragam menunjukkan bahwa perlakuan suhu dan waktu pengeringan tidak berpengaruh nyata $(\mathrm{P}>0,05)$ terhadap rasa teh herbal celup daun belimbing wuluh yang dilakukan dengan uji hedonik. Tabel 5 menunjukkan bahwa nilai rata-rata rasa teh herbal celup daun belimbing wuluh tertinggi diperoleh pada perlakuan suhu pengeringan $70^{\circ} \mathrm{C}$ dengan waktu 120 menit dengan nilai 3,04 (agak suka) sedangkan nilai rata-rata rasa teh herbal celup daun belimbing wuluh terendah diperoleh pada perlakuan suhu pengeringan $50^{\circ} \mathrm{C}$ dengan waktu 240 menit dengan nilai 2,80 (agak suka) dengan kriteria agak suka. Menurut Winarno (1997), perubahan yang terjadi pada cita rasa bahan pangan biasanya lebih kompleks dari pada warna bahan pangan.

\section{Penerimaan keseluruhan}

Hasil sidik ragam menunjukkan bahwa suhu dan waktu pengeringan tidak berpengaruh nyata $(\mathrm{P}>0,05)$ terhadap penerimaan keseluruhan minuman teh herbal celup daun belimbing wuluh. Tabel 5 menunjukkan bahwa nilai rata- rata uji hedonik terhadap penerimaan keseluruhan minuman teh herbal daun belimbing wuluh berkisar antara 3,04 (agak suka) sampai dengan 3,40 (agak suka). Penerimaan keseluruhan minuman teh herbal dipengaruhi oleh beberapa faktor seperti warna, aroma, dan rasa.

\section{KESIMPULAN DAN SARAN}

\section{Kesimpulan}

Interaksi suhu dan waktu pengeringan berpengaruh sangat nyata terhadap kadar air, kadar fenol, kadar total flavonoid, aktivitas antioksidan, dan rasa sepat (uji skoring). Namun, interaksi suhu dan waktu pengeringan berpengaruh tidak nyata terhadap warna (uji hedonik), aroma (uji hedonik), rasa (uji hedonik), dan penerimaan keseluruhan (uji hedonik) teh herbal celup daun belimbing wuluh. Perlakuan terbaik yang dapat digunakan untuk menghasilkan teh herbal celup daun belimbing wuluh yaitu suhu pengeringan $50^{\circ} \mathrm{C}$ dengan waktu 120 menit. Perlakuan tersebut mampu menghasilkan aktivitas antioksidan sebesar $87,8049 \%$ dan berdasarkan nilai IC $_{50}$ sebesar 
10595,95 ppm, kadar air 9,53\%, kadar total fenol $1,38 \mathrm{mg} \mathrm{GAE} / \mathrm{g}$, kadar total flavonoid $0,94 \mathrm{mg}$ $\mathrm{QE} / \mathrm{g}$, dan sifat sensoris dengan warna (suka), aroma (agak suka), rasa (agak sepat, agak suka) dan penerimaan keseluruhan (agak suka).

\section{Saran}

Berdasarkan hasil penelitian, untuk memperoleh teh herbal daun belimbing wuluh karakteristik terbaik menggunakan suhu $50^{\circ} \mathrm{C}$ dengan waktu selama 120 menit. Namun disarankan untuk dilakukan kajian lebih lanjut terkait penggunaan suhu pengeringan dibawah $50^{\circ} \mathrm{C}$ dan waktu pengeringan diatas 120 menit dalam pembuatan teh herbal celup daun belimbing wuluh.

\section{UCAPAN TERIMAKASIH}

Puji syukur penulis haturkan kepada Tuhan Yang Maha Esa karena penelitian ini bisa berjalan dengan lancar. Penulis juga mengucapkan terimakasih kepada berbagai pihak yang telah turut membantu dalam penelitian ini.

\section{DAFTAR PUSTAKA}

Adri, D dan W. Hersoelistyorini. 2013. Aktivitas Antioksidan dan Sifat Organoleptik Teh Daun Sirsak (Annona Muricata L.) Berdasarkan Lama Pengeringan. Jurnal Pangan Dan Gizi. 4(7): 2-34.

Afriani. 2008. Kualitas dan Potensi Dadih sebagai Tambahan Pendapatan Peternak Kerbau Di Kabupaten Kerinci. Jurnal Ilmu-Ilmu Peternakan, 11(3) 115-120.

Andarwulan, N., C.H. Wijaya, dan D.T. Cahyono. 1996. Aktivitas Antioksidan dari Daun Sirih (Piper Betle L.). Buletin Teknologi Dan Industri Pangan. 7:29-37.

Aprillia, M., N.W. Wisaniyasa, dan I.K. Suter. 2020. Pengaruh Suhu dan Lama Pelayuan terhadap Karakteristik Teh Herbal Daun
Kenikir (Cosmos Caudatus Kunth.). Jurnal Itepa. 9(2): 136-150.

Dewi, N. L. P. D. U., L. P. Wrasiati., dan D. A. A. Yuarini. 2016. Pengaruh Suhu dan Lama Penyangraian dengan Oven Dryer terhadap Karakteristik Teh Beras Merah Jatiluwih. Jurnal Online Mahasiswa (JOM) Bidang Pertanian, 4(2):1-9.

Dewi, W. K., N. Harun., dan Y. Zalfiatri. 2017. Pemanfaatan Daun Katuk (Sauropus Adrogynum) dalam Pembuatan Teh Herbal dengan Variasi Suhu dan Waktu Pengeringan. Jurnal Online Mahasiswa (JOM) Bidang Pertanian, 4(2):1-12.

Fello, P. J. 1998. Food Processing Technology. Principle and Practive. Ellis Horwood. New York

Hartuti, N., dan R.M. Sinaga. 1997. Pengeringan Cabai. Balai Penelitian Tanaman Sayuran. Pusat Penelitian dan Pengembangan Hortikultura. Badan Penelitian dan Pengembangan Pertanian.

Liliana, W. 2005. Kajian Proses Pembuatan Teh Herbal dari Seledri (Apium Graveolens L.). Jurnal Teknologi Pangan. Institut Pertanian Bogor, Bogor.14-19.

Martini,N.K.A., I.G.A. Ekawati dan P.T. Ina. 2020. Pengaruh Suhu dan Lama Pengeringan terhadap Karakteristik Teh Bunga Telang (Clitoria Ternatea L.). Jurnal ITEPA. 9(3):327-340.

Mus, C., 2012. Belimbing Wuluh. Www.Plantamor. Com. Diakses Tanggal 23 September 2014.

Neuma, H.J. 1972. Dehydrated Celery: Effect of Predrying Treatment and Rehydration Procedure are Reconstitution. J.Food.Sci.73:437-441.

Patras, A., N.P. Brunton, S. Da-Pieve, F. Butler, and G. Downey. (2009). Effect of Thermal and High Pressure Processing on Antioxidant Activity and Instrumental Colour of Tomato and Carrot Purees. Innovative Food Science and Emerging Technologies. 10(1): 16-22.

Prabandari, I. M. 2015. Pengaruh Lama Penyimpanan dan Perebusan Daun Sirsak Segar (Annona Muricata Linn) terhadap Aktivitas Antioksidan Sari Daun Sirsak. Skripsi. Fakultas Teknologi Pertanian. Institut Pertanian, Bogor.

Rahmawati, D. 2004. Mempelajari Aktivitas Antioksidan dan Mikroba Ekstrak Antarasa 
(Litsea Cubeba) dan Aplikasinya sebagai Pengawet Alami pada Bahan Pangan. Skripsi. Fakultas Teknologi Pertanian IPB, Bogor.

Robinson, T. 1995. Kandungan Senyawa Organik Tumbuhan Tinggi. Terjemahan Kokasih Padmawinata. Bandung : ITB.

Sakanata, S., Y. Tachibana., dan Y. Okada. 2003. Preparation and Antioxiant Properties of Extracts of Japanese Persimo Leaf Tea (Kakinocha-Cha). Food Chemistry. 89:569575.

Sari, G. P., 2011. Studi Budidaya dan Pengaruh Lama terhadap Jahe Merah (Zinggiber Officinale Rosc.). Skripsi. Tidak Dipublikasikan. Fakultas Pertanian dan Peternakan Universitas Islam Negri Sultan Syarif Kasim, Riau.

Sari, M.A. 2015. Aktivitas Antioksidan Teh Daun Alpukat (Persea Americana Mill) dengan Variasi Teknik dan Lama Pengeringan. Skripsi. Tidak Dipublikasikan. Fakultas Keguruan dan Ilmu Pendidikan, Universitas Muhammadiyah, Surakarta.

Simanjuntak, L., N. Harun, Dan R. Efendi. 2014. Penerimaan Panelis terhadap Teh Herbal dari Kulit Buah Manggis (Garcinia Mangostana L.) dengan Perlakuan Suhu Pengeringan. Jurnal Online Mahasiswa Pertanian. 1(1): 111.

Soekarto, S.T. 1985. Penelitian Organoleptik untuk Industri Pangan dan Hasil Pertanian. Bharata Karya Aksara, Jakarta.

Sompong, R., S. Siebenhandl-Ehn, G. LinsbergerMartin, dan E. Berghofer. 2011. Physicochemical and Antioxidative Properties of Red and Black Rice Varieties from Thailand, China and Sri Lanka. Food Chemistry. 124(1): 132-140

Sudarmadji, S., B. Haryono. dan Suhardi. 1997. Prosedur Analisa untuk Bahan Makanan dan Pertanian. Liberty. Yogyakarta.

Suksmadji, B. 1987. Beberapa Sifat Pati Gaplek. Fakultas Pertanian Pasca Sarjana UGM, Yogyakarta.
Susanti, D. Y., 2008. Efek Suhu Pengeringan terhadap Kandungan Fenolik dan Kandungan Katekin Ekstrak Daun Kering Gambir. Prosiding Seminar Nasioanal Teknik Pertanian. Yogyakarta.

Thomas, A.N.S. 2007. Tanaman Obat Tradisional 2. Kanisius. Yogyakarta.

Valsan A., Dan R.K. Raphael. 2016. Pharmacognostic Profile of Averrhoa Bilimbi Linn. Leaves. Journal Of Biol Sci.2(1): 75-80.

Verma, A. Alpana. 2014. Optimization and Quality Assessment of Low - Calorie Herbal Tea Sweetened with Stevia (Stevia Rebaudiana). Journal of Medical Research and Development. 3(2): 134-137.

Winarno, F.G. 1995. Kimia Pangan dan Gizi. PT Gramedia Pustaka Utama. Jakarta.

Winarno, F.G. 1997. Kimia Pangan dan Gizi. PT Gramedia Pustaka Utama, Jakarta.

Winarsi, H. 2007. Antioksidan Alami dan Radikal Bebas Potensi dan Aplikasi dalam Kesehatan. Kanisius, Yogyakarta.

Wulandari, K. 2009. Pengaruh Cara Pengeringan terhadap Perolehan Kadar Senyawa Fenolat dan Aktivitas Antioksidan dari Daun Dewa (Gynura Procumbens (Lour.) Merr). Skripsi. Padang: Universitas Andalas.

Yamin, M., D.W. Ayu, dan F. Hamzah. 2017. Lama Pengeringan terhadap Aktivitas Antioksidan dan Mutu Teh Herbal Daun Ketepeng Cina (Cassia Alata L.). FAPERTA. 4:13.

Zainol, M.M.K, A.A. Hamid, A. Bakar, Dan P. Dek. 2009. Effect of Different Drying Methods on The Degradation of Selested Flavonoids in Centella Asiatica. International Food Research Journal. 16:531-537.

Zuhra, C.F., J. B. Tarigan dan H. Sihotang. 2008. Aktivitas Antioksidan Senyawa Flavonoid dari Daun Katuk (Sauropus Androgunus (L) Merr.). J Biol Sumatera. 3(1):7-10. 